\title{
Evaluasi Komposisi Tubuh dan Pemanfaatan Nutrien di Ambing Kambing Peranakan Etawah Laktasi yang Diberi Pakan Fermentasi Limbah Tempe
}

\author{
Evaluation of Body Composition and Nutrient Uptake on the Mammary Gland of Ettawah Crossbred Goat Lactation Fed \\ by Fermented Tempeh Waste \\ D A Astuti', E B Laconi'
}

Corresponding email: dewiapriastuti@yahoo.com

1)Departemen Ilmu Nutrisi dan Teknologi Pakan, Fakultas Peternakan, Institut Pertanian Bogor (Bogor Agricultural University/IPB University)

\section{ABSTRACT}

The aim of this study was to evaluate the body composition, nutrient uptake in mammary gland and milk amino acid profile of lactating Etawah Crossbred goats fed by tempeh by product. Twelve lactating goats were randomly allocated into three groups which fed by ration containing concentrate (R1), concentrate plus $25 \%$ fresh tempeh waste (R2) and concentrate plus $25 \%$ fermented tempeh waste (R3). Tempeh waste was fermented by Aspergillus niger. Kinggrass was given $50 \%$ of the total ration for all groups. Urea space technique was used to measure body composition before and after the experiment was done. Milk production was calculated two times a day during two months after giving birth (postpartum). Total milk protein and amino acid, whey and casein were analyzed by kjeldahl method and amino acid analyzer respectively. Nutrient uptake in mammary gland was calculated base on Fick principles. Result showed that there was significantly different on body weight, but on body water, protein and fat had no significant difference between the treatments. The best milk production was found in fermented tempeh waste group. Concentration of glutamic acid was dominant than other essential amino acids in whole milk and casein but there were no significant difference between groups for those essential amino acid profile. It was concluded that fermented tempeh waste could substitute $50 \%$ of total concentrate and had the highest body weight,,milk yield and nutrient uptake in the mammary gland of lactating Etawah Crossbred goats.

Key words: body composition, fermentation, lactating PE goat, nutrient uptake, tempeh waste

\section{ABSTRAK}

Penelitian ini bertujuan untuk mengevaluasi komposisi tubuh dengan teknik ruang urea, serapan nutrien di kelenjar ambing dan profil asam amino kambing peranakan etawah (PE) laktasi dengan pemberian limbah tempe. Sebanyak 12 ekor kambing PE laktasi secara random dibagi dalam 3 kelompok perlakuan yaitu diberi ransum mengandung konsentrat (R1), ransum mengandung konsentrat ditambah 25\% limbah tempe segar (R2) dan ransum mengandung konsentrat ditambah 25\% limbah tempe fermentasi (R3). Limbah tempe difermentasi dengan jamur Aspergilus niger dan rumput gajah diberikan sebanyak $50 \%$ dari total ransum. Pengukuran komposisi tubuh dilakukan dengan metoda ruang urea pada saat awal dan akhir pengamatan sedangkan produksi susu di ukur 2 kali sehari selama 2 bulan pengamatan sejak melahirkan. Total protein dan asam amino susu, whey dan casein dianalisis dengan metoda kjehldal dan amino acid analyzer. Serapan nutrien diukur berdasarkan azas Fick. Hasil penelitian menunjukkan bahwa ada perbedaan nyata $(\mathrm{P}<0,05)$ pada pertumbuhan dan produksi susu, dengan perlakuan R3 yang tertinggi, sedangkan komposisi tubuh tidak berbeda pada semua perlakuan. Persentase asam amino glutamin dominan dibandingkan dengan asam amino lainnya, baik pada total susu, whey dan casein, namun tidak ada perbedaan yang nyata pada semua perlakuan. Kesimpulan bahwa perlakuan fermentasi limbah tempe dapat menggantikan $50 \%$ dari total konsentrat dan menghasilkan pertumbuhan dan produksi susu yang terbaik.

Kata kunci: fermentasi, kambing PE, komposisi tubuh, limbah tempe, uptake nutrisi 


\section{PENDAHULUAN}

Permasalahan harga pakan ternak masih didominasi oleh tingginya harga bahan pakan sumber protein. Alternatif bahan pengganti sumber protein telah banyak dikaji oleh para peneliti dengan hasil yang bervariasi tergantung kualitas bahan. Pada proses pembuatan tempe dihasilkan banyak limbah, baik yang berupa limbah padat maupun limbah cair (Badan Pengendalian Limbah 2000). Limbah padat berupa kulit kedelai yang rusak dan kedelai yang busuk dapat dijadikan sumber serat untuk pakan ruminansia. Limbah tersebut masih mengandung protein yang cukup tinggi yaitu sekitar 16\% (Astuti et al. 2000). Proses fermentasi limbah tempe dengan kapang Aspergilus niger dapat membantu proses penguraian serat limbah sehingga mudah dicerna (Laconi et al. 2017).

Susu kambing lebih dapat dicerna oleh anak-anak karena sifat molekulnya yang kecil, kandungan vitamin A tinggi dan asam aminonya tidak mudah menekan kerja sistem kekebalan tubuh (tidak alergik), maka susu kambing ini merupakan mimunan kesehatan yang sangat menjanjikan untuk kecerdasan dan peningkatan SDM anak-anak dan balita (Park 1991). Susu kambing mempunyai beberapa kelebihan dibandingkan dengan susu sapi yaitu a) memiliki molekul protein yang lebih kecil sehingga mudah dicerna, b) memiliki molekul globular lemak yang lebih tipis yang berguna untuk kontrol flavor, c) mengandung mineral penting yang tinggi seperti : $\mathrm{Ca}, \mathrm{P}, \mathrm{Mg}, \mathrm{K}, \mathrm{Cl}, \mathrm{Mg}$ dan $\mathrm{Se}$, d) mengandung enzim xantinoxidase yang rendah sehingga kurang mengakibatkan kerusakan arteri (arteriosclerosis) dan sel jantung, e) rendah asam lemak oratat yang berpengaruh terhadap pencegahan penyakit Fatty Lever Syndrom, f) mengandung asam amino L-glutamin yang tinggi yang berfungsi sebagai alkalinizing (menaikkan $\mathrm{pH}$ darah), g) susu kambing dapat diminum oleh orang yang mempunyai masalah lactosa intolerant, h) mengandung asam lemak caprat, caprylat dan caproat yang tinggi sehingga berguna sebagai antibakterial, i) susu kambing lebih terbebas dari kontaminan karena dipelihara dalam skala kecil dan dalam pakannya bebas antibiotik, pestisida dan BST (Lehninger 1982; Bishop et al. 1990; Park 1991).

Kambing peranakan etawah merupakan ternak yang mempunyai potensi penghasil susu, disamping sebagai ternak potong. Produksi yang optimum dipengaruhi oleh pakan yang memegang peranan penting dalam menyediakan nutrien untuk dijadikan produk. Penyediaan pakan yang berkualitas akan berpengaruh terhadap harga, oleh karena itu penggantian bahan pakan sumber protein akan dapat menekan harga. Limbah pabrik tempe merupakan salah satu alternatif bahan yang dapat digunakan dalam ransum kambing perah PE dengan harapan dapat mempertahankan produksi dan kualitas air susunya. Produktivitas susu kambing di Indonesia belum mencapai optimum. Ambing sebagai pabrik susu perlu dioptimalkan kerjanya melalui peningkatan efisiensi dalam memanfaatkan substrat yang masuk. Glukosa, asam amino dan trigliserida yang diserap ambing merupakan prekursor laktosa, protein dan lemak susu (Waghorn et al. 1984). Data menunjukkan bahwa metabolisme glukosa dan efisiensi penggunaan glukosa oleh ambing berkisar 50 - 87\% dengan perbedaan hijauan yang diberikan (Chaiyabutr et al. 2000). Penelitian ini bertujuan untuk mengevaluasi pemberian limbah tempe yang difermentasi terhadap komposisi tubuh dan serapan nutrien di ambing kambing peranakan etawah.

\section{METODE}

Pada penelitian ini digunakan dua belas ekor kambing PE laktasi kedua dengan bobot badan rataan $50 \pm 3 \mathrm{~kg}$ dan secara random dibagi ke dalam tiga kelompok perlakuan ransum berbasis limbah ampas tempe dengan rancangan acak kelompok, pola searah. Perlakuan pertama (R1) mendapat konsentrat sebagai kontrol, perlakuan kedua (R2) mendapat konsentrat ditambah limbah tempe segar (1:1) dan perlakuan ketiga (R3) mendapat konsentrat ditambah limbah tempe yang telah difermentasi dengan Aspergilus niger (1:1). Proses fermentasi limbah tempe dilakukan pada nampan plastik dengan menebar limbah tempe basah setinggi 3 sampai $5 \mathrm{~cm}$, kemudian ditebarkan 1\% Aspergilus niger. Rumput kinggrass diberikan $50 \%$ dari total ransum untuk semua perlakuan. Ransum diberikan ad libitum. Kualitas ransum untuk kambing laktasi mengacu pada tabel kebutuhan pakan NRC (1990). Rancangan perlakuan terdapat pada Tabel 1, dan komposisi nutrien ransum perlakuan terdapat pada Tabel 2 .

Pemberian ransum dilakukan sehari dua kali dengan maksimum pemberian $4 \%$ bahan kering dari bobot badannya dan air minum diberikan ad libitum. Sisa pakan ditimbang keesokan harinya guna menghitung konsumsi harian. Masa adaptasi pakan dilakukan sejak kambing masih bunting umur 4 bulan dan pengukuran konsumsi mulai dilakukan sejak kambing beranak hingga selesai

Tabel 1 Perlakuan ransum yang diberikan pada kambing PE laktasi

\begin{tabular}{lccc}
\hline Perlakuan & R1 & R2 & R3 \\
\hline Rumput gajah & $50 \%$ & $50 \%$ & $50 \%$ \\
Konsentrat & $50 \%$ & $25 \%$ & $25 \%$ \\
Ampas segar & - & $25 \%$ & - \\
Ampas fermentasi & - & - & $25 \%$ \\
\hline R1 = ransum kontrol, R2= ransum ampas tempe segar, & \\
R3 = ransum ampas fermentasi & &
\end{tabular}


Tabel 2 Komposisi nutrien ransum perlakuan

\begin{tabular}{lrrr}
\hline Komposisi (\%) & R1 & R2 & R3 \\
\hline Bahan kering & 91,22 & 93,74 & 94,02 \\
Protein kasar & 13,99 & 14,25 & 14,10 \\
Ekstrak eter & 4,83 & 3,99 & 3,80 \\
Serat kasar & 20,61 & 29,94 & 29,27
\end{tabular}

R1 = ransum kontrol, R2= ransum ampas tempe segar,

$\mathrm{R} 3$ = ransum ampas fermentasi

laktasi (dua bulan pasca beranak).

Teknik ruang urea digunakan untuk mengukur komposisi tubuh pada awal dan akhir pengamatan (Panaretto and Till, 1963). Sebelum dilakukan pengukuran ruang urea darah diambil terlebih dahulu melalui vena jugular untuk mengetahui kadar urea awal, kemudian larutan urea $20 \%$ sebanyak $0,65 \mathrm{ml}$ dari bobot badan metabolik disuntikan melalui vena jugularis selama 1 menit (secara perlahan). Setelah 12 menit dari urea masuk, darah diambil kembali dan langsung dianalisis kadar urea darah dengan methoda KIT- BUN (blood urea nitrogen). Adapun rumus perhitungan yang digunakan menurut Panaretto \& Till (1963) adalah :

$$
\begin{array}{ll}
\text { Ruang Urea (\%) } & =\frac{\text { dosis Urea }(\mathrm{mg})}{[(\text { Urea } 12-\text { Urea } 0) \times 10 \times \mathrm{BB}]} \\
\text { Air tubuh }(\%) & =59,1+((0,22 \times \% \text { ruang urea })-0,04 \mathrm{BB}) \\
\text { Protein tubuh }(\%) & =0,265 \times \% \text { Air Tubuh }-0,47 \\
\text { Lemak tubuh }(\%) & =98-1,32 \times \% \text { Air Tubuh }
\end{array}
$$

Produksi susu diukur 2 kali sehari selama 2 bulan sejak beranak, sedangkan total protein dan asam amino di whey, casein dan susu dianalisis berdasarkan metoda standar di laboratorium yang berlaku (kjeldahl method and amino acid analyzer). Pengambilan darah dilakukan secara langsung dibagian vena ambing dan arteri carotis communis untuk mendapatkan data kadar glukosa, trigliserida, total protein, asam asetat, gas darah $\mathrm{PO}_{2}$ dan $\mathrm{PCO}_{2}$ ). Analisis $\mathrm{PO}_{2}$ dan $\mathrm{PCO}_{2}$ dilakukan dengan alat blood gas analyzer (Shapiro 1982), sedangkan analisis glukosa, trigliserida dan total protein dilakukan dengan menggunakan KIT- DyaSis. Nilai serapan metabolit di organ ambing diperoleh dengan azas Fick yang menyatakan besarnya serapan nutrien di organ adalah merupakan perkalian laju alir darah ke organ tersebut dengan nilai selisih nutrien di arteri dan vena. Laju alir darah (LAD) ke ambing dihitung berdasarkan rumus yang dikembangkan oleh Cant et al. 1993).

LAD ambing $(\mathrm{l} / \mathrm{jam})=\{($ FybX 0,965) + Fyf $\} /$ Fy a-v

Fyb = phe-tyr di protein susu (mol/mnt)

Fyf = phe-tyr di protein free milk (mol/mnt)

Fy $\mathrm{a}-\mathrm{v}=$ delta phe-tyr di arteri dan vena ambing (mol/mnt)

Serapan nutrien $(\mathrm{mg} / \mathrm{min})=$ LAD X (nutrien arteri nutrien vena)

\section{Analisis Data}

Data yang diperoleh dianalisis ANOVA dari model Rancangan Acak Kelompok pola searah dengan bobot badan sebagai kelompok rendah, sedang dan tinggi dan perbedaan antar perlakuan diuji lanjut dengan Duncan Multiple Range Test (Steel and Torrie 1993).

\section{HASIL DAN PEMBAHASAN}

Hasil analisis komposisi tubuh dengan metoda ruang urea tidak tampak adanya perbedaan persentase air, protein dan lemak tubuh antarperlakuan, namun bila dikalikan dengan masing-masing bobot badan maka hasil riil kompoisisi tubuh berbeda (Tabel 3). Bobot badan pada perlakukan R3 dengan pemberian ampas tempe fermentasi menunjukkan perbedaan nyata dibandingkan dengan R1 dan R2 $(\mathrm{P}<0,05)$. Hal ini disebabkan tingginya nilai serapan nutrien yang tercerminkan pada konsentrasi metabolit darah, yang artinya total air, protein dan lemak tubuh pada perlakuan pemberian fermentasi limbah tempe adalah tertinggi. Rataan persentase air tubuh pada penelitian kambing perah ini berkisar 65\%, lebih tinggi dibandingkan persentase air tubuh pada domba priangan penggemukan yang berkisar antara 57\% dan domba lokal jonggol (Astuti et al. 1999; Astuti et al. 2015). Tingginya air tubuh pada kambing perah disebabkan konsumsi air minum pada kambing perah lebih tinggi untuk menunjang produksi susunya. Persentase lemak tubuh pada kambing laktasi ini tampak cukup tinggi yaitu mencapai $22 \%$, hal ini disebabkan kambing laktasi ini sedang periode produksi (susu) dan sudah mencapai umur dewasa sehingga ada kecenderungan mulai perlemakan. Data ini berbeda dengan hasil yang didapat pada pengukuran komposisi tubuh domba tumbuh dengan metoda ruang urea yang diberi ransum konsentrat, dengan persentase kadar lemak tubuh sekitar $9 \%$ (Astuti et al. 1998).

Pada Tabel 4 menunjukkan hasil produksi dan komposisi susu kambing peranakan etawah yang diberi pakan limbah tempe. Perlakuan fermentasi ampas tempe

Tabel 3 Komposisi tubuh kambing PE laktasi yang diberi pakan ampas tempe

\begin{tabular}{lrrr}
\hline Parameter & $\mathrm{R} 1$ & $\mathrm{R} 2$ & $\mathrm{R} 3$ \\
\hline Bobot badan (kg) & $48,10^{\mathrm{b}}$ & $50,50^{\mathrm{b}}$ & $58,70^{\mathrm{a}}$ \\
Air tubuh (\%) & 65,40 & 65,10 & 65,60 \\
Protein tubuh (\%) & 16,87 & 16,10 & 16,99 \\
Lemak tubuh (\%) & 22,40 & 22,90 & 22,54 \\
Total air tubuh (g) & $31,46^{\mathrm{b}}$ & $32,88^{\mathrm{b}}$ & $38,51^{\mathrm{a}}$ \\
Total protein tubuh (g) & $8,11^{\mathrm{b}}$ & $8,13^{\mathrm{b}}$ & $9,97^{\mathrm{a}}$ \\
Total lemak tubuh (g) & $10,77^{\mathrm{b}}$ & $11,56^{\mathrm{b}}$ & $13,23^{\mathrm{a}}$ \\
\hline
\end{tabular}

R1 = ransum kontrol, R2= ransum ampas tempe segar,

$\mathrm{R} 3$ = ransum ampas fermentasi

Superskrip yang berbeda pada baris yang sama menunjukkan perbedaan $\mathrm{p}<0,05$ 
Tabel 4 Jumlah dan komposisi susu Kambing PE laktasi

\begin{tabular}{lrrr}
\hline Parameter & R1 & R2 & R3 \\
\hline Produksi susu $\left(\mathrm{ml} \mathrm{h}^{-1}\right)$ & $1072^{\mathrm{b}}$ & $700^{\mathrm{c}}$ & $1544^{\mathrm{a}}$ \\
Total protein susu $\left(\mathrm{g} \mathrm{h}^{-1}\right)$ & $51,46^{\mathrm{b}}$ & $29,89^{\mathrm{c}}$ & $74,88^{\mathrm{a}}$ \\
Total lemak susu $\left(\mathrm{g} \mathrm{h}^{-1}\right)$ & $42,88^{\mathrm{b}}$ & $29,05^{\mathrm{c}}$ & $63,30^{\mathrm{a}}$ \\
Total laktosa susu $\left(\mathrm{g} \mathrm{h}^{-1}\right)$ & $37,52^{\mathrm{b}}$ & $27,30^{\mathrm{c}}$ & $63,30^{\mathrm{a}}$
\end{tabular}

R1 = ransum kontrol, R2= ransum ampas tempe segar,

R3 = ransum ampas fermentasi

Superskrip yang berbeda pada baris yang sama menunjukkan perbedaan $\mathrm{p}<0,01$

dengan Aspergilus niger memberikan respon yang terbaik dibandingkan dengan perlakuan lainnya $(\mathrm{P}<0,05)$, sehingga total protein, lemak dan laktosa susu juga lebih baik dibandingkan perlakuan R1 dan R2. Produksi susu pada penelitian ini jauh lebih tinggi dibandingkan dengan hasil penelitian sebelumnya pada kambing PE laktasi pertama yang diberi pakan konsentrat sampai dengan $60 \%$ (Astuti et al. 2000). Riis (1983) melaporkan komposisi susu kambing adalah sebagai berikut : lemak 3,7\% , laktosa $4,8 \%$ dan protein 3,3\%. Pendapat ini menunjukkan tidak jauh beda dengan hasil penelitian ini.

Data kandungan nutrien di darah arteri dan vena pada Tabel 5 menunjukkan bahwa terjadi penggunaan nutrien di tingkat organ ambing, hal ini terlihat dari lebih rendahnya konsentrasi nutrien di vena ambing dibandingkan dengan di arteri. Tidak ada pengaruh perlakuan terhadap konsentrasi nutrien di darah arteri dan vena ambing untuk semua perlakuan, hal ini disebabkan jumlah ulangan yang sedikit (2 ekor tiap perlakuan). Riis (1983) melaporkan bahwa konsentrasi nutrien di arteri beberapa metabolit adalah sebagai berikut : glukosa $55 \mathrm{mg} 100 \mathrm{ml}^{-1}$; asam asetat 8,8 mg 100 $\mathrm{ml}^{-1}$; NEFA $15,6 \mathrm{mg} 100 \mathrm{ml}^{-1}$ dan asam amino $28,4 \mathrm{mg}$ $100 \mathrm{ml}^{-1}$. Asam amino yang paling dominan hadir pada

Tabel 5 Kandungan nutrien di arteri dan vena kambing PE laktasi

\begin{tabular}{lrrr}
\hline Parameter & $\mathrm{R} 1$ & $\mathrm{R} 2$ & $\mathrm{R} 3$ \\
\hline Glukosa (mg\%) & & & \\
- Arteri & 55 & 60 & 79 \\
- Vena Ambing & 38 & 41 & 55 \\
Trigliserida (mg\%) & & & \\
- Arteri & 27 & 33 & 35 \\
- Vena Ambing & 17 & 18 & 17 \\
Protein (mg\%) & & & \\
- Arteri & 11,70 & 11,90 & 13,38 \\
- Vena Ambing & 8,70 & 7,75 & 9,38 \\
Asetat (mM) & & & \\
- Arteri & 5,07 & 4,43 & 6,96 \\
- Vena Ambing & 4,97 & 4,36 & 6,81 \\
PO (mmHg) & & & \\
- Arteri & 82 & 86 & 91 \\
- Vena Ambing & 33 & 41 & 31 \\
\hline R1 & &
\end{tabular}

R1 = ransum kontrol, R2 = ransum ampas tempe segar,

$\mathrm{R} 3$ = ransum ampas fermentasi susu kambing penelitian ini adalah glutamat, baik pada tingkat whey maupun caseinnya. Sementara hasil uji degradasi protein di rumen menghasilkan derivat purin yang menunjukkan bahwa serapan asam amino di darah dapat berasal dari sintesis protein mikroba (Astuti et al. 2002). Metabolit darah berupa glukosa, total protein dan trigliserida pada domba lokal lebih rendah dibandingkan dengan data pada kambing perah yang sedang laktasi (Astuti et al. 2011). Hal ini menjelaskan bahwa nutrien yang hadir di darah dapat dipengaruhi oleh jumlah serapan di usus dan status fisiologi ternak.

Menurut Bruhn et al. (1999) susu kambing mengandung lemak 3,90 \% dan kolesterol 11-25 mg 100g-1 (lebih tinggi dibanding susu sapi yaitu $14-17 \mathrm{mg}$ 100 g-1 susu). Kandungan protein susu sebesar 3,56\% (lebih rendah dari susu sapi) dan tidak bersifat alergik. Asam amino yang dominan pada susu kambing adalah glutamin (Tabel 6), hal ini secara genetik memang sudah diturunkan dari tetuanya. Asam amino ini sangat dibutuhkan untuk perkembangan otak, oleh sebab itu minuman susu sangat diperlukan oleh anak yang sedang tumbuh. Rovanis et al. (1995) melaporkan asam amino susu kambing mengandung komposisi sebagai berikut phe, leu, isoleu, thre, met, lys, val, pro, ala, asp, ser, glu, dan tir berturut-turut adalah $0,15 \% ; 0,31 \% ; 0,21 \%$; $0,16 \% ; 0,08 \% ; 0,29 \% ; 0,24 \% ; 0,37 \% ; 0,12 \% ; 0,21 \%$; $0,18 \% ; 0,63 \%$ dan $0,18 \%$. Hasil penelitian ini dengan perlakuan limbah tempe sebagai pakan kambing PE laktasi menghasilkan kandungan glutamin sebesar 0,72\% (R2) dan 0,94\% (R3) yang artinya lebih tinggi dibandingkan dengan perlakuan kontrolnya $(0,51 \%)$ dan pendapat peneliti sebelumnya $(0,63 \%)$. Asam amino glutamin ini sangat diperlukan untuk pertumbuhan otak.

Tabel 6 Kandungan asam amino (\%) di total susu, whey dan casein kambing PE laktasi

\begin{tabular}{llllllllll}
\hline Asam & S1 & S2 & S3 & W1 & W2 & W3 & C1 & C2 & C3 \\
\hline Asp & 0,19 & 0,25 & 0,34 & 0,06 & 0,05 & 0,06 & 1,62 & 1,00 & 1,85 \\
Glu & 0,51 & 0,72 & 0,94 & 0,09 & 0,08 & 0,09 & 5,37 & 2,96 & 6,58 \\
Ser & 0,14 & 0,19 & 0,24 & 0,03 & 0,03 & 0,03 & 1,36 & 0,84 & 1,69 \\
His & 0,07 & 0,10 & 0,13 & 0,01 & 0,01 & 0,01 & 1,02 & 0,48 & 1,20 \\
Glys & 0,04 & 0,04 & 0,08 & 0,01 & 0,01 & 0,02 & 0,43 & 0,28 & 0,49 \\
Thre & 0,11 & 0,17 & 0,20 & 0,03 & 0,03 & 0,03 & 1,13 & 0,67 & 1,37 \\
Arg & 0,05 & 0,10 & 0,13 & 0,02 & 0,01 & 0,02 & 0,77 & 0,48 & 0,90 \\
Ala & 0,08 & 0,11 & 0,14 & 0,03 & 0,03 & 0,03 & 0,63 & 0,44 & 0,77 \\
Tyr & 0,08 & 0,12 & 0,17 & 0,01 & 0,01 & 0,01 & 0,10 & 0,65 & 1,21 \\
Met & 0,06 & 0,08 & 0,10 & 0,01 & 0,01 & 0,01 & 0,72 & 0,39 & 0,84 \\
Val & 0,14 & 0,22 & 0,32 & 0,03 & 0,03 & 0,03 & 1,99 & 1,10 & 2,26 \\
Phe & 0,12 & 0,16 & 0,21 & 0,02 & 0,02 & 0,02 & 1,34 & 0,79 & 1,57 \\
Ileu & 0,11 & 0,16 & 0,21 & 0,02 & 0,02 & 0,03 & 1,27 & 0,77 & 1,49 \\
Leu & 0,22 & 0,31 & 0,41 & 0,05 & 0,05 & 0,05 & 2,47 & 1,46 & 2,91 \\
Lys & 0,18 & 0,26 & 0,33 & 0,05 & 0,05 & 0,05 & 1,91 & 1,19 & 2,37 \\
\hline & & & & & & & & &
\end{tabular}


Tabel 7 Serapan metabolit nutrien di ambing kambing PE laktasi

\begin{tabular}{llll}
\hline Parameter & R1 & R2 & R3 \\
\hline Glukosa (mg min-1) & $51 \mathrm{~b}$ & $35 \mathrm{c}$ & $72 \mathrm{a}$ \\
Trigliserida (mg min-1) & $45 \mathrm{~b}$ & $30 \mathrm{c}$ & $54 \mathrm{a}$ \\
Total protein (mg min-1) & $45 \mathrm{~b}$ & $38 \mathrm{c}$ & $60 \mathrm{a}$ \\
Asetat (mM min-1) & $30 \mathrm{~b}$ & $21 \mathrm{c}$ & $45 \mathrm{a}$
\end{tabular}

$\mathrm{R} 1$ = ransum kontrol, R2= ransum ampas tempe segar,

R3 = ransum ampas fermentasi

Superskrip yang berbeda pada baris yang sama menunjukkan perbedaan $\mathrm{p}<0,01$

Data serapan nutrien di ambing (Tabel 7) menunjukkan kinerja ambing dalam memproduksi susu. Tampak bahwa perlakuan R3 nyata lebih tinggi dibandingkan dengan perlakuan kontrol $(\mathrm{P}<0,05)$. Tingginya kualitas bahan baku limbah tempe yang difermentasi dan diikuti dengan nilai serapan nutrien serta status metabolit darah yang dominan mengakibatkan tingginya produksi susu pada perlakuan R3. Besarnya jumlah rataan glukosa, trigliserida dan protein yang diserap ke ambing dan diekspresikan menjadi laktosa, lemak dan protein susu masing-masing sebesar 64\%, 58\% dan 76\%. Jadi tidak semua nutrien yang diserap akan diubah menjadi produk nutrien susu. Besarnya serapan glukosa diambing untuk menjadi produksi laktosa susu adalah sebagai berikut : untuk R1 sekitar 6,8 g 100 $\mathrm{ml}^{-1}$ susu; R2 sekitar 7,2 g 100ml-1 susu dan R3 sekitar 6,6 g $100 \mathrm{ml}^{-1}$ susu. Riis (1983) menyatakan bahwa serapan glukosa di ambing kambing

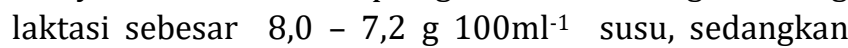
untuk nutrien lain seperti asetat dan asam amino

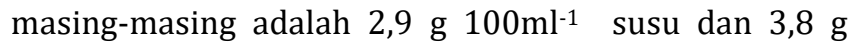
$100 \mathrm{ml}^{-1}$ susu. Chaiyabutr et al. (2000) menyatakan bahwa metabolisme glukosa dan efisiensi penggunaan glukosa oleh ambing berkisar 50\% - 87\% dengan perlakuan hijauan yang berbeda.

\section{SIMPULAN}

Limbah tempe yang difermentasi dengan Aspergilus niger dapat menggantikan $50 \%$ penggunaan konsentrat komersial dan dapat meningkatkan bobot badan, serapan nutrien diambing dan produksi susu kambing peranakan etawah. Komposisi tubuh dengan teknik ruang urea pada semua perlakuan tidak berbeda.

\section{DAFTAR PUSTAKA}

Astuti DA \& Sastradipradja D. 1998. Measurement of body composition using slaughter technique and urea-space in local sheep. Indonesian Journal of Veterinary Science. 3: 1-9

Astuti DA \& Sastradipradja D. 1999. Evaluation of body composition using urea dilution and slaughter technique of growing Priangan sheep. Media Veteriner. 6 (3) : 5-9.

Astuti DA, Sastradipradja D \& Sutardi T. 2000. Nutrient balance and glucose metabolism of female growing, late pregnant and lactating ettawah crossbred goats. Asian-Australasian Journal of Animal Sciences. 13:8: 1068-1077

Astuti DA\& Wina E. 2002. Protein balance and excreation of purine derivatives in urine of lactating etawah crossbred goats fed with tempe waste. Jurnal Peternakan dan Veteriner. 7(3) : 162-166

Astuti DA, Baba AS \& Wibawan IWT. 2011. Rumen fermentation, blood metabolites, and performance of sheep fed tropical browse plants. Media Peternakan. 34 (3) : 201-206

Astuti DA \& Sudarman A. 2015. Status fisiologi, profil darah dan komposisi tubuh domba yang diberi minyak lemuru tersaponifikasi dan disalut dengan herbal. Buletin Peternakan. 39 (2): 116-122.

Badan Pengendalian Pengendalian Dampak Lingkungan Daerah. 2000. Laporan Pertanggungjawaban Pembangunan Instalasi Pengolahan Limbah Cair Industri Tahu Tempe PRIMKOPTI Ngoto Yogyakarta. Yogyakarta (ID) : Setwilda Propinsi DIY

Bishop JM, Hill, DJ, \& Hosking CS. 1990. Goat milk does not suppress the immune system. Journal of Pediatrics. 116: 862-867

Bruhn JC, FST \& Davis CA. 1999. Dairy goat milk composition. https://drinc.ucdavis.edu/goat-dairy-foods/dairy-goat-milkcomposition

Cant JP, DePeters EJ \& Baldwin RL, 1993. Mammary amino acid utilization in dairy cows fed fat and its relationship to milk protein depression. Journal of Dairy Science. 76 (3) :762-774

Chaiyabutr N, Komolvanich S, Preuksagorn S \& Chanpongsang S. 2000. Comparative studies on the utilization of glucose in the mammary gland of crossbred holstein cattle feeding on different types of roughage during different stages of lactation. AsianAustralasian Journal of Animal Sciences. 13 (3): 334 - 347.

Laconi EB, \& Jayanegara A. 2015. Improving nutritional quality of cocoa pod (theobroma cacao) through chemical and biological treatments for ruminant feeding: in vitro and in vivo evaluation. Asian-Australasian Journal of Animal Sciences Open Access. http://dx.doi.org/10.5713/ajas.13.0798.

Lehninger AL. 1982. Principles of Biochemistry. New York (US): Woth Publisher, Inc.

NRC. 1990. Nutrient Requirement of Goat. Washington (US): National Academy of Science.

Panaretto BA \& Till A.R.. 1963. Body compositition in vivo. II. The composition of mature goats and its relationship to the antypyrene, tritiated water and acetyl-4-aminoantipyrene spaces. Australian Journal of Agricultural Research. 14 (6): 926 943

Park YW. 1991. Goat milk as a substitute for those who are lactose intolerant. Journal of Dairy Science 74:3326-3333

Riis PM. 1983. Dynamic Biochemistry of Animal Production. New York (US): Elsevier Science

Rovanis. 1995. Letters in applied microbiology. Journal of Milk and Food Technology. 20 (3): 164-167

Steel RGD \& Torrie JH, 1993. Principles and Procedures of Statistics. New York (US): McGraw Hill Book Co. Inc.

Shapiro BA, Harrison RA \& Walton JR, 1982. Clinical Application of Blood Gas. $3^{\text {rd }}$ ed. London (UK): Book Medical Publishers, Inc.

Waghorn GC \& Baldwin, RL. 1984. Model of metabolic flux within mammary gland of the lactating cows. Journal of Dairy Science. 67: $531-544$ 